\title{
KOMPARATIVNA ANDRAGOGIIA
}

\section{(Dušan Savičević, Beograd: Inštitut za pedagogiju $i$ andragogiju Filozofskog fakulteta Univerziteta u Beogradu, 2003, 359 strani)}

$\mathrm{D}$ ušan Savičević, profesor na beograjski univerzi, je eden od vidnejših avtorjev andragoških besedil v bivši Jugoslaviji. Poznan je po svojih delih s področja filozofije in zgodovine vzgoje in izobraževanja odraslih, pisal je o splošnih temah in tudi o posameznih področjih, kot je denimo družinska andragogika. Njegovo ime navajajo evropski in tudi ameriški avtorji. Knowles opisuje srečanje z njim in njegov vpliv nanj, da je tudi sam začel uporabljati termin andragogika. Savičević je bil tisti, ki je Knowlesa navdušil za izbiro poimenovanja. Četudi se je beseda andragogika pojavljala na ameriških tleh že z Lindemanom, je bilo ravno srečanje $s$ Savičevićem tako prepričljivo, da je začel Knowles svoje delo označevati s terminom andragoško.

\section{Spoznavanje preko primerjanja}

Lansko leto je izšla Savičevićeva knjiga z naslovom Komparativna andragogika. Avtor uporablja komparacijo kot način spoznavanja dogajanj $\mathrm{v}$ andragogiki, s primerjalno metodo izrisuje sodobne vplive globalizacije in tudi vplive dogajanja $v$ preteklosti na vzgojo in izobraževanje odraslih. Poleg komparativnega pristopa uporablja pri svoji raziskavi in interpretaciji tudi historične in hermenevtične metode.

Besedilo je razdeljeno na osem delov. V prvem delu $\mathrm{z}$ naslovom Komparativne perspektive izobraževanja in učenja odraslih pokaže na prepletenost izobraževanja odraslih in družbenega razvoja, na odnos med tradicijo in sodobnostjo, na pozitivne in negativne plasti globalizacije. Izobraževanje pokaže kot tisto področje, kjer se križajo vplivi ekonomije, politike, tehnike, znanosti in kulture. Skozi celotno besedilo opozarja na družbene, ekonomske in politične vplive. Izobraževanje opredeli kot duševni proces, da je tudi družbeni proces, lahko sklepamo iz besedila, ne dotakne pa se povezav med izobraževanjem in delovanjem možganov, med andragogiko in nevroznanostmi. Kot bi ostajal pri kartezijanski delitvi človeka na telo in duha, kjer andragogiko zanima drugi del.

Izobraževanje je splošna dobrina (srb. opšte ljudsko dobro), za označevanje ne uporablja termina pravica, kot se pojavlja v aktualnih dokumentih, niti izobraževanja ne prikazuje kot tržnega proizvoda, kot blaga, ki se zamenjuje in kupuje. Savičević se zavzema za družbeno aktivno izobraževanje, ki je nasprotujoče izobraževanju kot potrošnji. Eden od ciljev andragoške akcije je neposredna demokracija. V svojih pogledih je podoben Freireju in sodobnemu ameriškemu avtorju Petru McLarenu, ki ga nekateri imenujejo tudi revolucionarni pedagog.

Fenomen funkcionalne pismenosti prinaša 
nove izzive $\mathrm{v}$ izobraževanju odraslih $\mathrm{v}$ industrijsko razvitih državah. Nizke stopnje funkcionalne pismenosti razlagajo kot posledico ekonomske in tehnološke transformacije družbe. Avtor navaja podatke za ZDA, kako obsežne težave imajo s pisanjem in branjem nezaposleni ljudje. O pismenosti slikovito govori zanimiva izkušnja indijske družbe $v$ ěasu pred in med oblastjo britanskih kolonizatorjev. Po površnem in hitrem sklepanju bi lahko mislili, da je britanska kolonizacija Indije vplivala tudi na zviševanje pismenosti prebivalstva. Savičević ugotavlja nasprotno. Pismenost je bila $v$ Indiji bolj razširjena $v$ začetku 19. stoletja, ko so Britanci vzpostavili svojo vladavino, kot pa v začetku 20. stoletja. Leta 1911 je bilo v Indiji več nepismenih kot leta 1835. Komparativisti razlagajo pojav $\mathrm{z}$ zamenjavo izobraževalnega sistema. Indija je imela svoj sistem, ki je bil povezan z religijo in je deloval, ker je bil ukoreninjen v kulturi. Angleži so vzpostavili šolski sistem po svojem vzoru, ki ni bil enako učinkovit.

Učinkoviti izobraževalni sistemi so tesno povezani s kulturo okolja, z zgodovino in s problemi ljudi. Savičević sklene razmišljanje, da če želimo vzpostaviti nove sisteme, lahko ti privedejo do nasprotnega učinka, kot bi si ga želeli.

Drugi del nosi naslov historično-komparativna proučevanja $v$ andragogiki in prinaša sprehod $v$ časovno dimenzijo od antike prek srednjega veka do novejših paradigem. Nadaljuje se z opisovanjem dogajanja v Jugoslaviji $v$ tretjem delu in $v$ četrtem delu osvetli mednarodne dimenzije izobraževanja odraslih s primerjavo med industrijsko razvitimi državami in državami v razvoju, ki jih deli glede na prevladujoči religiozni tok. Presenetljive so njegove ugotovitve, da imajo mnogi moderni pojmi v izobraževanju odraslih na Zahodu, kot npr. povratno izobraževanje, učenje $\mathrm{z}$ lastnim tempom in učeča se družba, korenine $v$ islamu in drugih religijah. Implicitno po- kaže na časocentrizem sodobnega zăhodnega človeka, ki je prepričan, da si je večino novosti izmislil sam. Ko naleti na zgodovinske podatke, zavzdihne, kot je napisal Mark Twain: "V preteklosti so nam ukradli zamisli."

$\mathrm{V}$ petem delu avtor kritično tematizira problem razpršenosti terminologije in se zavzame za jezikovno poenotenje $\mathrm{v}$ andragoških primerjavah. Primerjalna analiza pokaže, da je terminologija na področju izobraževanja odraslih jezikovno, kulturno in filozofsko vprašanje. Terminologija se je namreč oblikovala v določenih kulturnih okoljih, na izbor besed so vplivali posamezni filozofski tokovi. Beseda training (angl.) označuje usposabljanje, ki se razlikuje od izobraževanja, ker ne vsebuje razvoja osebnosti, vrednot. Potemtakem je lahko training tudi nemoralno in nekoristno učenje. Termin je nastal $v$ povezavi z angleško prakso in z gibanjem taylorizma, ko so želeli pri delavcih "natrenirati" vse delovne gibe, da ne bodo izgubljali časa $\mathrm{z}$ odvečnimi gibi. "Training within industry" se iz industrije v 20. stóletju prenese tudi na druga profesionalna področja, nastane izraz job training, ki označuje pridobivanje, razvijanje znanja in veščin $v$ času dela, $z$ delom. V ZDA so razvili širšo paradigmo za izobraževanje zaposlenih, ki so jo poimenovali HRM (human resources management). Natančnost terminologije je odraz zrelosti neke znanstverie discipline in po tem pokazatelju je andragogika mlada veda. Potrebno bi bilo termine standardizirati in o njih kritično razmišljati, saj so nekatere besede brez premisleka sposojene iz drugih ved.

$\mathrm{V}$ šestem delu Savičević prikaže metodološki okvir komparativne andragogike, v sedmem pa pot konstituiranja komparativne andragogike kot akademske discipline. Andragogika se po njegovih besedah ne sme zadovoljiti z naključnim odkrivanjem, marveč potrebuje profesionalne raziskovalce in razisko- 
valke, sicer bodo vzgojo in izobraževanje raziskovali drugi strokovnjaki, kar v andragogiko prinaša mnogo amaterizma.

\section{Kaj lahko zapišemo ob koncu?}

Besedilo ni zanimivo le zá komparativiste, ampak za širši strokovni krog, saj prinaša odgovore na nekatera aktualna vprašanja, kot je vprašanje o imenu znanstvene discipline in o upoštevanju zgodovine in kulture pri reformah. Eksplicitno pokaže na pomembno vlogo jugoslovanske andragogike, katere del je bila tudi slovenska, v evropskem in svetovnem merilu, Jugoslavija je bila leta 1919 ena od ustanoviteljic Svetovnega združenja za izobraževanje odraslih. Po tem letu se je začelo tudi teoretsko utemeljevanje in profesionalizacija področja. Študij andragogike se je začel denimo na British Columbia University v akademskem letu 1958-59, v Jugoslaviji v 60, letih (v Ljubljani v 70.) 20, stoletja; s svojim pisanjem pokaže, da sta Jugoslavija, in s tem tudi Slovenija, že v sedemdesetih letih imeli marsikaj, kar je ponekod nastajalo šele $v$ devetdesetih letih.

Dr. Nives Ličen 